2. To: (Receiving Organization)

Plant/Equipment Engineering

5. Proj./Prog./Dept./Div.:

OSP/TW- 03

8. Originator Remarks:

This EDT is for approval and release of RPP-6180, Rev. 0
3. From: (Originating Organization)

operations Special Projects

6. Design Authority/Design Agent/Cog. Engr.:

C.C. Scaief III
4. Related EDT No.:

$\mathrm{N} / \mathrm{A}$

7. Purchase Order No

$\mathrm{N} / \mathrm{A}$

9. Equip./Component No.:

$\mathrm{N} / \mathrm{A}$

10. System/Bldg./Facility:

200-G

12. Major Assm. Dwg. No.:

$\mathrm{N} / \mathrm{A}$

13. PermitPermit Application No.

$\mathrm{N} / \mathrm{A}$

14. Required Response Date:

$\mathrm{N} / \mathrm{A}$

\begin{tabular}{|c|c|c|c|c|c|c|c|c|}
\hline 15. & & DATA TR & NSMITTE & & (F) & (G) & $(H)$ & (I) \\
\hline $\begin{array}{l}\text { (A) } \\
\text { Item } \\
\text { No. }\end{array}$ & (B) Document/Drawing No. & $\begin{array}{l}\text { (C) Sheet } \\
\text { No. }\end{array}$ & $\begin{array}{l}\text { (D) Rev. } \\
\text { No. }\end{array}$ & (E) Title or Description of Data Transmitted & $\begin{array}{l}\text { Approval } \\
\text { Desig- } \\
\text { nator }\end{array}$ & $\begin{array}{c}\text { Reason } \\
\text { for Trans- } \\
\text { mittal }\end{array}$ & $\begin{array}{c}\text { Origi- } \\
\text { nator } \\
\text { Dispo- } \\
\text { stion }\end{array}$ & $\begin{array}{c}\text { Receiv- } \\
\text { er } \\
\text { Dispo- } \\
\text { sition }\end{array}$ \\
\hline 1 & RPP -6180 & - & 0 & ENGINEERING TASK PLAN FOR & $Q$ & 1 & 1 & 1 \\
\hline & & & & HEPA FILTER DIFFERENTIAL & & & & \\
\hline & & & & PRESSURE FAN INTERLOCK & & & & \\
\hline & & & & UPGRADES & & & & \\
\hline & & & & & & & & \\
\hline & & & & & & & & \\
\hline & & & & & & & & \\
\hline
\end{tabular}

16.

Approval Designator (F)

E, S, Q, D OR N/A (See WHC-CM-3-5 Sec. 12.7)

\begin{tabular}{ll}
\hline & \\
\hline 1. Approval \\
2. Release \\
3. Information
\end{tabular}

Reason for Transmittal (G)

4. Review

5. Post-Review

6. Dist. (Receipt Acknow. Required)
KEY
4. Reviewed no/comment

5. Reviewed w/comment

6. Receipt acknowledged
1. Approved

Approved w/comment

Disapproved w/comment
17.

(G)

\begin{tabular}{c|c}
$\begin{array}{c}\text { Rea- } \\
\text { son }\end{array}$ & $(\mathrm{H})$ \\
Disp
\end{tabular}

(J) Name

Design Authority C.C. Scaief I

1

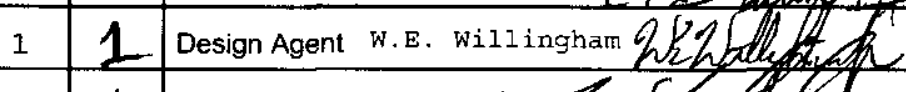

$11 /$ Cog. Eng. J. Lohrasbi

2 cog Mgr D.G.

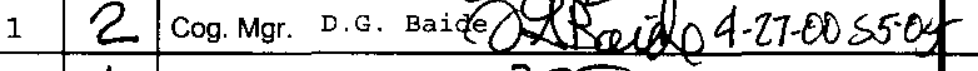

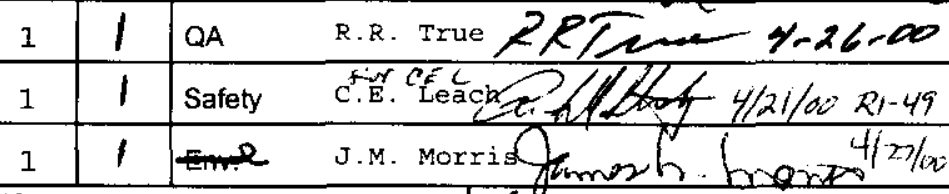

18.

Shaner Somant

Shawn R. Simons 4/21/00

Signature of EDT

Originator
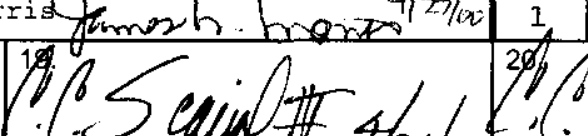

c.c. Scaief fII $42 / 80$ Authorized Representative for Receiving Organization

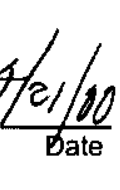

SIGNATURE/DISTRIBUTION

(See Approval Designator for required signatures)

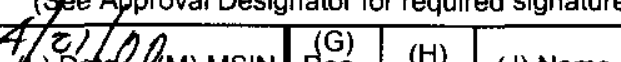

(J) Name

(K) Signature

(L) Date (M) MSIN

Disp.

proj.Mgr. K.E. Carpenter

Equi. Eng. R.D. Gustavson

cog.Eng. T.D. Kaiser langlar.

Cog.Mgr. R.E. Larson R/ foun $5 / 18 / 0$

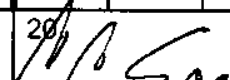

c.

c.C. Scaief II

Design Authority

Cognizant Manager

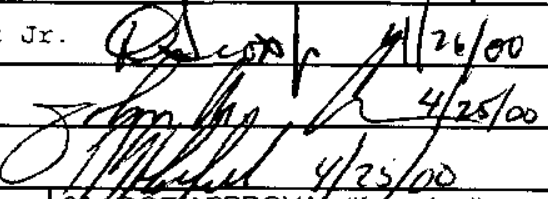

21. DOE APPROVAL (if required)

Ctrl No.

Approved

Approved w/comments

Disapproved w/comments 


\title{
ENGINEERING TASK PLAN FOR HEPA FILTER DIFFERENTIAL PRESSURE (DP) FAN INTERLOCK UPGRADES
}

\author{
Shawn R. Simons \\ for: CH2M-Hill Hanford Group, Inc. \\ Richland, WA 99352 \\ U.S. Department of Energy Contract DE-AC06-99RL14047

$\begin{array}{lll}\text { EDT/ECN: } & 626598 & \text { UC: } \mathrm{n} / \mathrm{a} \\ \text { Cost Center: } & 7 \mathrm{C} 200 & \text { Charge Code: CACN111281 } \\ \text { B\&R Code: } & \text { EW02J2030 } & \text { Total Pages: } 19\end{array}$

Key Words: Task plan, description, Acceptance for Beneficial Use checklist, organization, cost estimate and schedule, HEPA, primary ventilation, exhauster, fan interlock, differential pressure.

Abstract: This document provides a plan for installation of Differential Pressure (DP) fan interlocks on the primary ventilation systems in selected Tank Farm facilities. This plan contains the engineering tasks required for installation and is summarized by the Acceptance for Beneficial Use list. Individuals responsible for each task are identified and scheduled accordingly.

TRADEMARK DISCLAIMER. Reference herein to any specific commercial product, process, or service by trade name, trademark, manufacturer, or otherwise, does not necessarily constitute or imply its endorsement, recommendation, or favoring by the United States Government or any agency thereof or its contractors or subcontractors.

Printed in the United States of America. To obtain copies of this document, contact: Document Control Services, P.O. Box 950, Mailstop H6-08, Richland WA 99352, Phone (509) 372-2420; Fax (509) 376-4989.
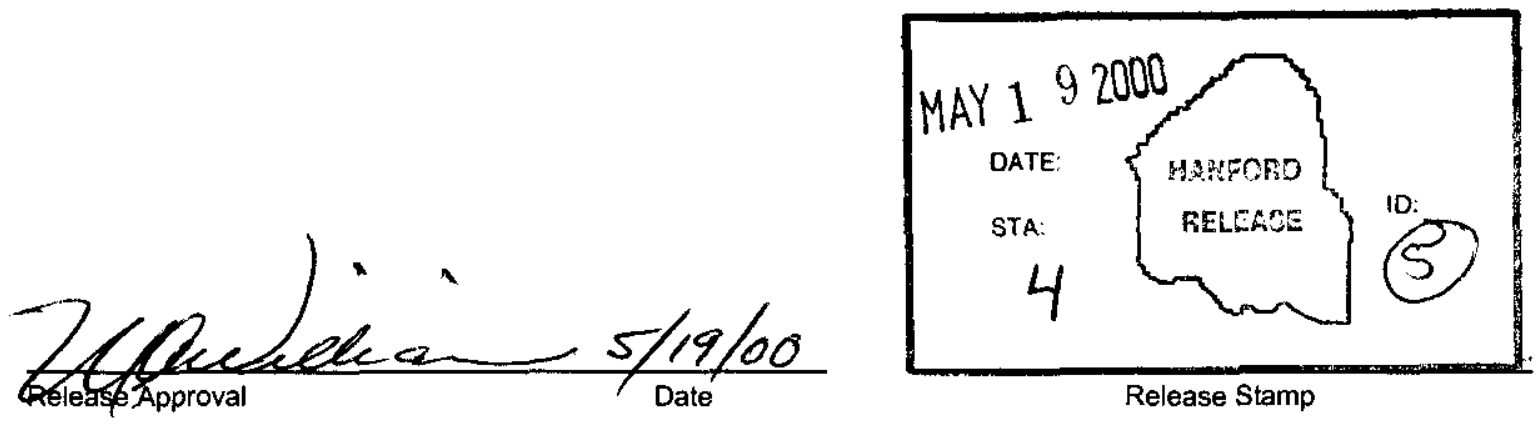

\section{Approved For Public Release}


RPP-6180, Rev. 0

\title{
ENGINEERING TASK PLAN
}

For

\section{HEPA FILTER DIFFERENTIAL PRESSURE FAN INTERLOCK UPGRADES}

\author{
Prepared for \\ Operations Special Projects \\ River Protection Project \\ CH2MHILL Hanford Group, Inc.
}

\section{Prepared By}

Shawn R. Simons

COGEMA Engineering Corporation

May 18, 2000 


\section{TABLE OF CONTENTS}

1.0 INTRODUCTION

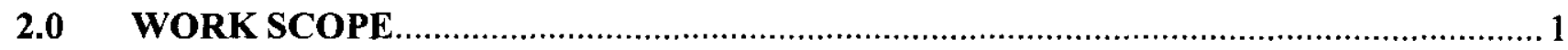

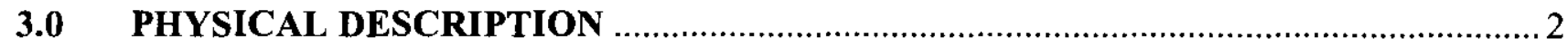

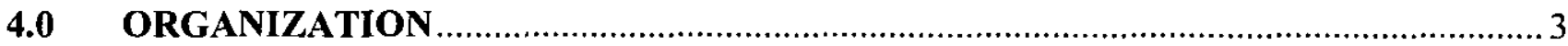

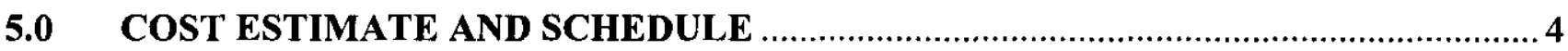

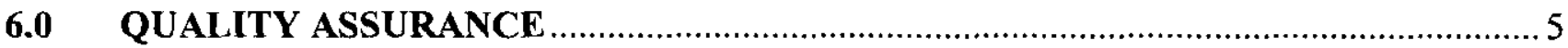

7.0 REFERENCES

Appendix A

Attachment B 
RPP-6180, Rev. 0

\subsection{INTRODUCTION}

Active ventilation exhaust stacks require a stack CAM interlock to detect releases from failed HEPA filters as a result of postulated accidents, and to shut down the exhaust fan when high radiation levels are detected in the stack airstream. Recently, it has been determined that an alternative system based on monitoring HEPA filter differential pressure (DP) is technically equivalent to the stack CAM interlocks and can perform its safety function (Gustavson 2000; ORP 2000). The alternative system can provide the requisite level of control specified in the facility safety analysis, and is expected to provide this function more reliably and with fewer operational and maintenance problems. Expected benefits include improved operating safety, reduced cost, and more reliable waste transfers or waste feed delivery. The tank farms operating contractor has been directed by DOE to implement the alternative system on active ventilation systems (ORP 1999). This Engineering Task Plan describes the effort necessary to provide the installation design, field installation and testing of DP interlocks on ventilation systems of selected tank farm facilities and provides guidance, responsibilities and requirements for the upgrades.

\subsection{WORK SCOPE}

\section{Project Management and Integration}

The scope of this activity is to perform Project Management and Project Integration activities for the installation of HEPA filter Differential Pressure (DP) interlock on the primary ventilation systems.

\section{Engineering}

The scope of this activity is to provide Engineering and Design for the installation of a HEPA filter Differential Pressure (DP) interlock on primary ventilation systems.

Deliverables for this activity include:

1. Engineering Task Plan

2. Safety Equipment List revision

3. Test and Evaluation Plan

4. Design Criteria Document

5. Vendor File Update

6. Spare Parts List, Available Spare Parts, and Master Equipment List

7. System Design Description (includes Structural Analysis)

8. Software Verification and Validation Report

9. Software Configuration Management Plan

10. Definitive Design Media including Engineering Change Notices (ECN) and Drawings

11. Un-reviewed Safety Question (USQ) reviews, as required

12. Engineering calculations and assessments, as required

\section{Procurement}

The scope of this activity is for the procurement of DP transmitters, PLCs, and other components that constitute the DP Interlock systems.

Subtask for this activity include:

1. Modify Evaluated Suppliers List 
2. Prepare Bill of Materials

3. Review and Approve Catalogue ID

4. Prepare Material Request

5. Material Receipt/Staging

6. Complete dedication of Commercial Grade Items (CGI) for procured parts (as appropriate)

\section{Procedures}

The scope of this activity is to prepare procedures with applicable Data Sheets for the operation and maintenance of a HEPA filter Differential Pressure (DP) fan interlock on active primary ventilation systems located in tank farms.

Subtasks for this activity include:

1. Prepare new and Modify existing Procedures for Alarm Response

2. Prepare/Modify Procedures for Calibrations

3. Prepare new and Modify existing ventilation Procedures for Operations

4. Prepare/Modify Procedures for Functional Testing

5. Prepare Operational Test Procedure (OTP)

6. Modify Surveillance Procedures

Work Packages, and Fieldwork

The scope of this activity is to prepare work packages and perform the fieldwork activities for the installation and testing of a HEPA filter Differential Pressure (DP) fan interlock on active primary ventilation systems located in tank farms.

Subtasks for this activity include:

1. Prepare and Issue Shop Pre-testing Work Package

2. Prepare and Issue Installation Work Package

3. Prepare work area/stage material/lock and tag

4. Conduct pre job

5. Conduct Plant Forces Work Review

6. Calibrate transmitters

7. Install systems

8. Perform OTP

9. Perform Functional Test Procedure

10. Complete work package

\subsection{PHYSICAL DESCRIPTION}

\section{System Definition and Safety Function}

A differential pressure (DP) system will be provided that measures HEPA filter airflow resistance, or pressure drop, and provides a safety related interlock function to shutdown the ventilation system in the event of a HEPA filter failure which may be caused by a filter loading condition (high $\Delta \mathrm{P}$ ).

The system design description, design requirements and Test and Evaluation Plan are to be documented as part of the task deliverables listed in Engineering of Section 2.0 above. 
The DP limits and operating modes for the proposed system are summarized in an approved $A B$ change (TSR controls). The ideal system design will provide the flexibility to support a reasonable range of operational settings, alarms, and interlocks as dictated by such analyses. The DP system is a generic design, capable of being installed and operated on facility ventilation systems at multiple locations (listed in Section 5.0, below) with minor site-specific engineering. The basic system design measures DP across the "first" (i.e., upstream) HEPA filter stage, "second" (i.e., downstream) HEPA filter stage, and the combined DP across the filter train (i.e., both HEPA filter stages in series). The system provides alarms at predetermined DP limits, and activates interlocks at selected alarm conditions to shut down the ventilation fan. The system will also be capable of communicating with remote locations via the Tank Monitor and Control System (TMACS).

\subsection{ORGANIZATION}

The following main tasks will be performed in support of this activity. Each task is described and responsible organizations and/or personnel have been identified.

\section{Project Management}

K. E. Carpenter is the Project Manager for these activities. Operations Special Projects (OSP) will provide Project Controls under management of K.E. Carpenter.

\section{Cognizant Engineering and Design Authority}

The Cognizant Engineers responsible for the overall upgrade activity are J. Lohrasbi (DST Engineering) and T.D. Kaiser (SST Engineering). Responsible Cognizant Engineering Managers are D.G. Baide (DST Engineering) and R.E. Larson (SST Engineering). C. C. Scaief III will provide technical assistance and will be Design Authority for the DP Interlock system design.

\section{Design Activities}

The design will consist of assembly drawings for the system and Engineering Change Notices (ECN) to existing drawings for the installation. The ECNs and as-built drawings will be prepared by Cogema Engineering as the qualified Design Agent, but will be released by CH2MHill Hanford Group, Inc. Design verification will be required and the method will be by formal design review for those systems that are safety class. For ECNs not affecting the safety function, other design verification methods may be used, but are subject to approval by the Design Authority. A USQ screening will also be required before the design is implemented in the field. Vendor Information (VI) files will be created for the DP transmitter and PLC as a minimum. The Design Agent will create VI files. OSP will be responsible for all USQ screenings, as required.

\section{Plant Forces Work Review}

A Plant Forces Work Review (Davis-Bacon) will be performed. The Production Control organization under management of R.H. Lipfert will be responsible for preparing the DavisBacon review and obtaining resolution. 


\section{Work Package Preparation}

The work packages for fabrication, procurement and installation will be prepared by the Production Control organization (R.H. Lipfert, mngr.).

\section{Procedures}

The functional and operational test procedures for the DP interlock system will be written to reflect any changes necessary as a result of the installation of the system. In addition, calibration, operating, and functional test procedures will be written. PM/S Data sheets will be prepared also. Surveillance Procedures will be modified accordingly. Writing of new procedures and revision of the procedures and data sheets will be performed by the CHG Procedures group under management of J.W. Comer. This will occur by Procedure Change Authorization (PCA) developing new procedures, or by a complete revision depending on the extent of the changes required.

\section{Authorization Basis}

Final installations will result in new DP interlocks on applicable primary ventilation systems. In order to use the DP interlocks for meeting a safety function, the FSAR and TSRs will require revision. The $\mathrm{AB}$ revision will allow use of a HEPA filter DP interlock system as a replacement control for the existing ventilation stack CAM interlock system. Preparation and approval of the $\mathrm{AB}$ revision will be the responsibility of TWRS Nuclear Safety and Licensing managed by C.E. Leach.

\section{Testing and Training}

Testing will be performed prior to and after installation as required. Final acceptance of the new DP interlock systems will be by successful completion of the associated Operational Test Procedures conducted by RPP facility operators. The Functional Test Procedure will be performed as part of the OTP. The Cabinets will be shop tested before they are installed in the field. The procedure for this testing will be written in the Work Packages. Testing will be formally documented. All operating and maintenance crews will receive proper training prior to all testing. Training will be outlined in the Training Plan prepared by J.M. Morris.

\section{Acceptance for Beneficial Use}

Appendix A contains an Acceptance for Beneficial Use (ABU) form with deliverable items checked and responsibilities. As required by HNF-IP-0842, Vol. IV, 3.12, a turnover supporting document will be prepared by Operation Special Projects (OSP) under management of K.E. Carpenter attesting to the completion of the items on the checklist. The turnover document will include a duplicate of the original ABU checklist, and a listing of the deliverable documents for reference and retrieval. Approval of the turnover document will constitute final acceptance.

\subsection{COST ESTIMATE AND SCHEDULE}

Costs for the various tasks are contained in the associated CEIS and TBR packages, activity ID numbers 240._63 and 190.363. There is a commitment to install the first seven DP interlocks by September 30, 2000 to meet the Performance Incentive (PI). The seven systems chosen, shown in the table below, have the highest priority and will fulfill this commitment. Installation and functional testing for these seven systems is planned by September 30, 2000. The remaining 
systems will be designed and installed in the order of priority as presented in the table below. The following is a list of 19 exhausters where the proposed DP system upgrades are planned (from Gustavson 2000): Both a stack number and a facility or system description identify exhausters.

\begin{tabular}{|c|c|}
\hline STACK NUMBER & FACILITY OR SYSTEM DESCRIPTION \\
\hline 296-A-25 & 244-A DCRT EXHAUSTER \\
\hline *296-A-26 & 204-AR UNLOADING FACILITY \\
\hline *296-A-27 & 241-AW PRIMARY \\
\hline *296-A-29 & 241-AN PRIMARY \\
\hline *296-A-40 & 241-AP PRIMARY \\
\hline$* 296-\mathrm{A}-42$ & 241-AY/AZ PRIMARY \\
\hline $296-B-28$ & 244-BX DCRT EXHAUSTER \\
\hline$* 296-\mathrm{C}-05$ & 244-CR VAULT EXHAUSTER \\
\hline $296-\mathrm{C}-06$ & $241-\mathrm{C}-106(\mathrm{~W}-320 / \mathrm{WRSS})$ \\
\hline 296-P-16 & 241-C-105/106 TANKS \\
\hline *296-P-23 & 241-SY PRIMARY \\
\hline $296-\mathrm{P}-28$ & 241-SY BACKUP \\
\hline $296-P-32$ & RMCS \#A (244-AR VAULT TANKS) \\
\hline 296-P-33 & RMCS \#B PORTABLE \\
\hline $296-\mathrm{P}-34$ & RMCS \#C PORTABLE \\
\hline $296-S-15$ & 241-SX TANKS \\
\hline $296-\mathrm{S}-22$ & 244-S DCRT EXHAUSTER \\
\hline $296-\mathrm{S}-25$ & 241-SY PRIMARY (NEW) \\
\hline $296-T-18$ & 244-TX DCRT EXHAUSTER \\
\hline
\end{tabular}

The seven stacks marked with an asterisk $\left(^{*}\right)$ are slated for DP interlock upgrades during FY 2000 (but subject to change); the remainder planned to be completed in the fiscal year 2001 . It should be noted that this is a tentative listing, as safety analysis revisions and various project activities are currently ongoing which may obviate the need to upgrade one or more of the above exhausters (or change the order in which the upgrades are executed). The schedule for design completion and installation of these systems for FY2000 and FY2001 is provided in detail as Attachment B.

\subsection{QUALITY ASSURANCE}

Quality Assurance program requirements from Title 10, Code of Federal Regulations, Part 830.120 (10CFR 830.120) "Quality Assurance", and U.S. Department of Energy (DOE) Order 414.1A, "Quality Assurance", form the bases for the CHG Quality Assurance program. These requirements are implemented through RPP-MP-600, and HNF-IP-0842, Vol. XI, Sect. 1.1. Quality requirements for the DP fan interlock upgrades are derived from these documents and will be identified in engineering documents and work packages developed specifically for this effort or are already identified in existing documents which will be used as part of this effort. 
Procurement of items/components will be per RPP-PRO-268 and RPP-PRO-259, with some items/components procured as Safety related (SC or SS) with appropriate documentation. Quality Clauses shall be identified to assure component traceability, vendor qualification requirements, and Commercial Grade Item dedication process (as appropriate). The DP transmitters and PLCs will be procured as Safety Class and Quality Level "1" from an evaluated supplier. The Commercial Grade Items (CGI) dedication process will be used as applicable for Safety Class items not available from an evaluated supplier. Operations Special Projects (OSP) will modify the Evaluated Supplier List for the DP transmitters and PLCs with assistance by the Quality Assurance program.

Acceptance for Beneficial Use (ABU) of the HEPA Filter DP Interlock System must meet requirements of HNF-IP-0842, Vol. IV, Section 3.12. The process shall be documented to ensure all requirements have been met by the design and the system will reliably perform its safety function. Methods of qualification will include inspection and testing.

\subsection{REFERENCES}

HNF-SD-WM-SAR-067, TWRS Final Safety Analysis Report (FSAR), CH2MHill Hanford Group, Inc., Richland, Washington.

HNF-SD-WM-TSR-006, TWRS Technical Safety Requirements (TSR), CH2M-Hill Hanford Group, Inc., Richland, Washington.

HNF-IP-0842, RPP Administration, CH2M-Hill Hanford Group, Inc., Richland, Washington.

RPP-MP-600, Project Hanford Quality Assurance Program Description, CH2MHill Hanford Group, Inc., Richland, Washington.

Gustavson, R. D., 2000, Evaluation of Alternative Control for Prevention or Mitigation of HEPA Filter Failure Accidents at Tank Farm Facilities, RPP-5594, CH2M-Hill Hanford Group, Inc., Richland, Washington.

ORP, 1999, Implementation of Field Optimization, Contract No. DE-AC06-99RL14047, FY 2000 Performance Incentive ORP 3.2.3, Rev. 0, U.S. Department of Energy Office of River Protection, Richland, Washington.

ORP, 2000, Contract No. DE-AC06-99RL14047 - Partial Completion of Fiscal Year (FY) 2000 Performance Incentive ORP 3.2.3, Standard 2, and Section 4.2(a), Letter 00-TSD-012, J. J. Short to M. P. DeLozier, 15 February 2000.

RPP-5977, Rev. 0, HEPA Filter Differential Pressure Fan Interlock Upgrades Functional Requirements and Technical Design Criteria, CH2M-Hill Hanford Group, Inc., Richland, Washington. 
RPP-6180, Rev. 0

\section{Appendix A}

\begin{tabular}{|c|c|c|c|}
\hline \multicolumn{4}{|c|}{ DOCUMENTATION REQUIRED FOR ACCEPTANCE FOR BENEFICIAL USE } \\
\hline DESCRIPTION & RESPONSIBILITY & DESCRIPTION & RESPONSIBILITY \\
\hline 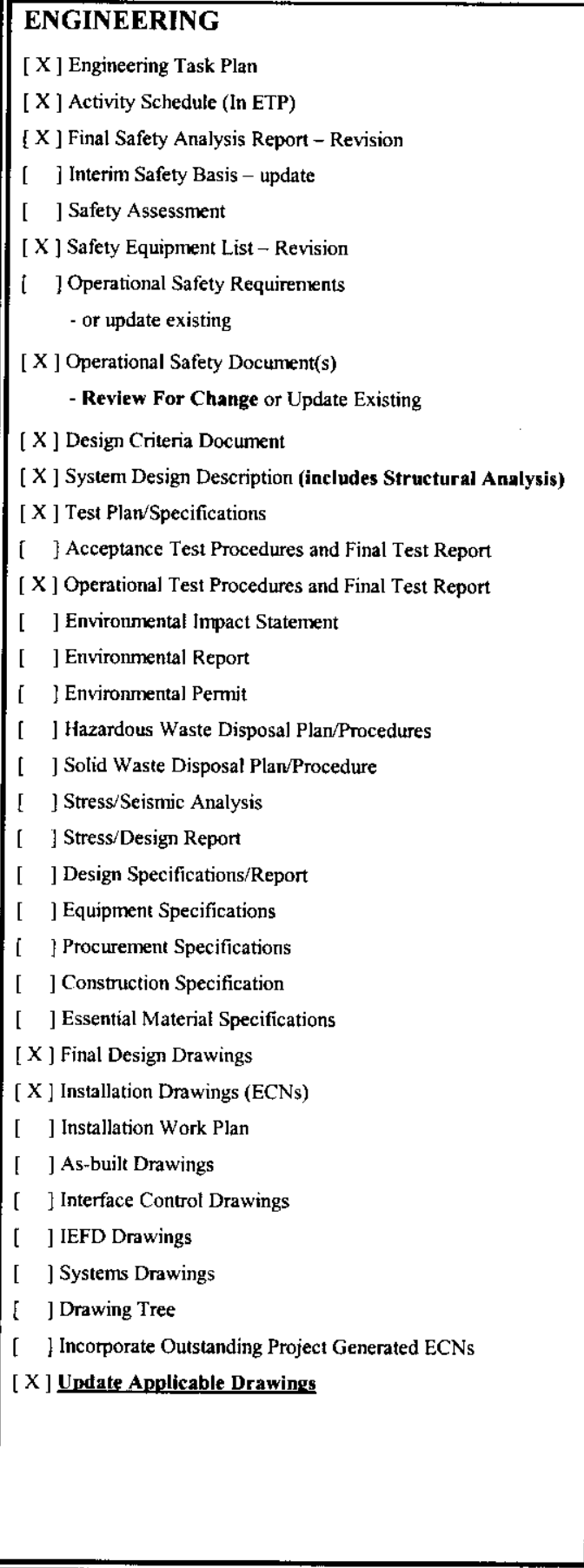 & $\begin{array}{l}\text { RD Gustavson } \\
\text { JA Tuck } \\
\text { WE Willingham } \\
\text { WE Willingham } \\
\text { JW Comer }\end{array}$ & 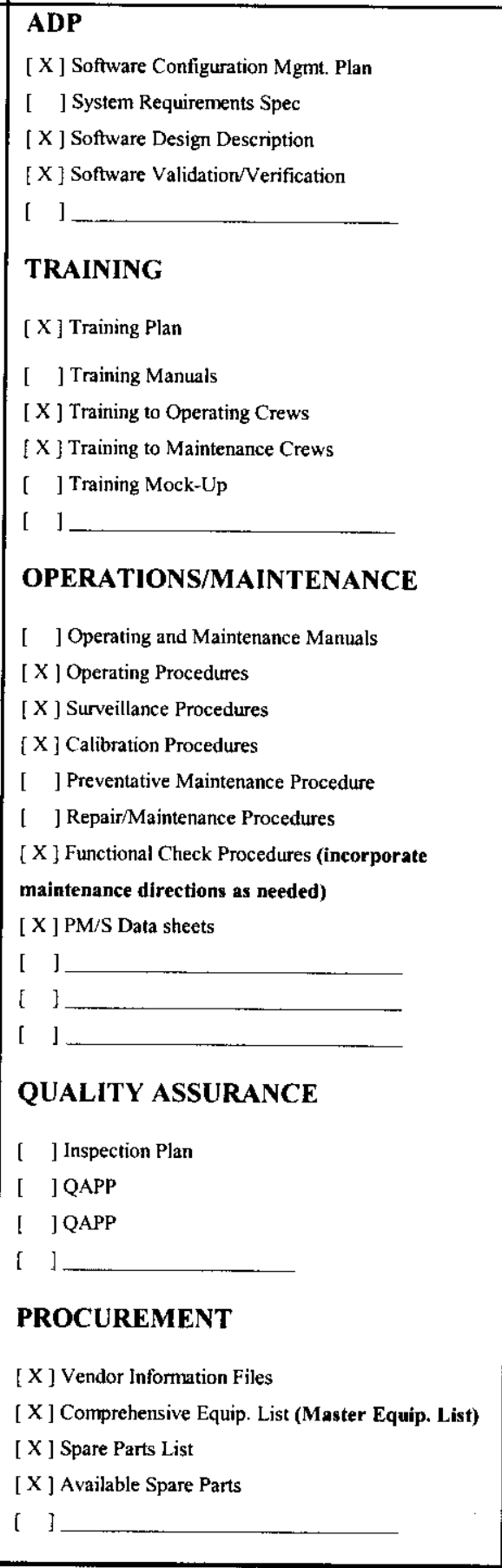 & $\begin{array}{l}\text { JW Comer } \\
\text { JW Comer } \\
\text { JW Comer } \\
\text { JW Comer } \\
\text { JW Comer }\end{array}$ \\
\hline
\end{tabular}




\section{Attachment B}

FY2000 - FY2001

Design and Installation Schedule

For

DP Interlock - PI 3.2.3 


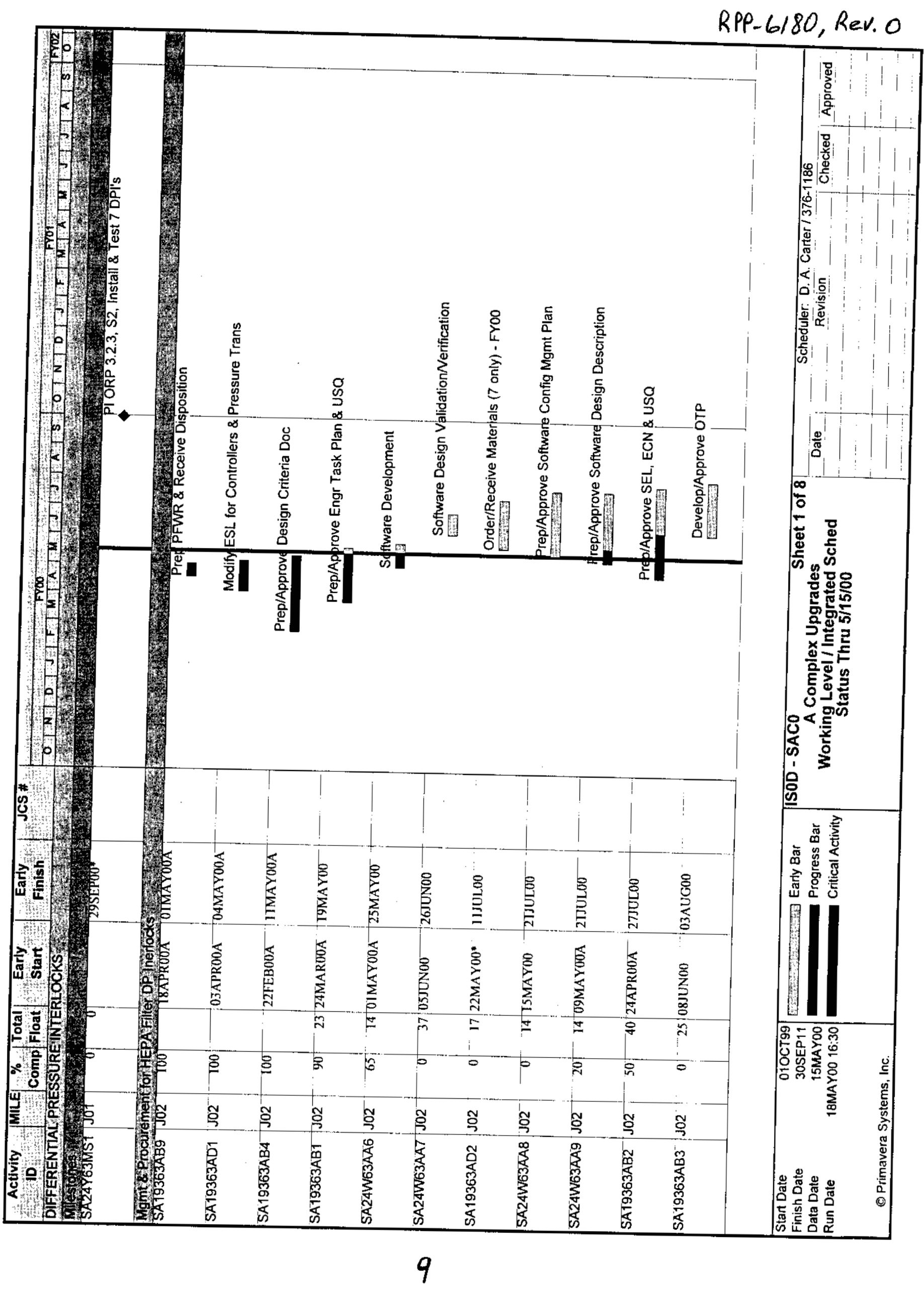


$\operatorname{RPP}-6180, \operatorname{Rev}, 0$

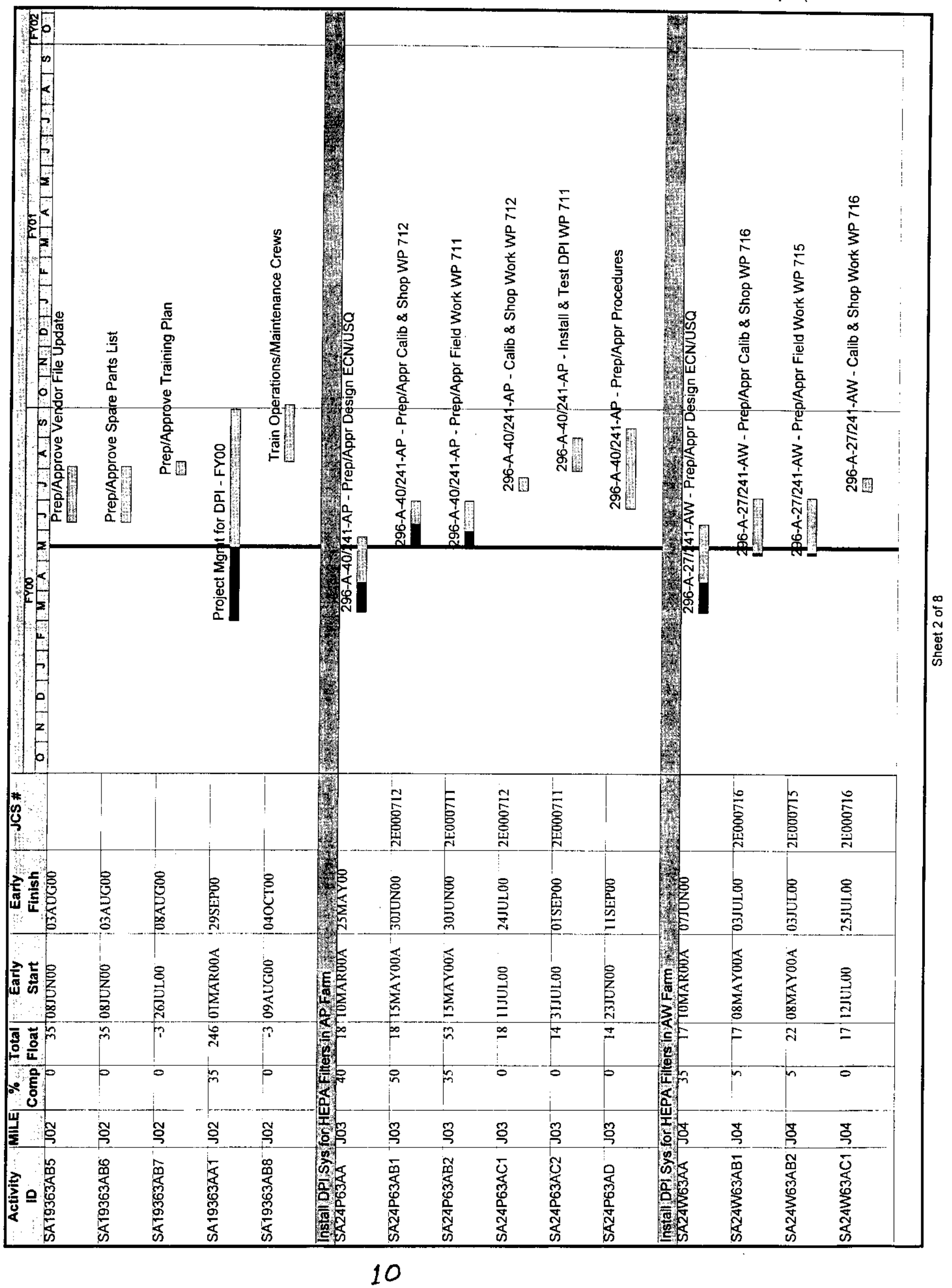




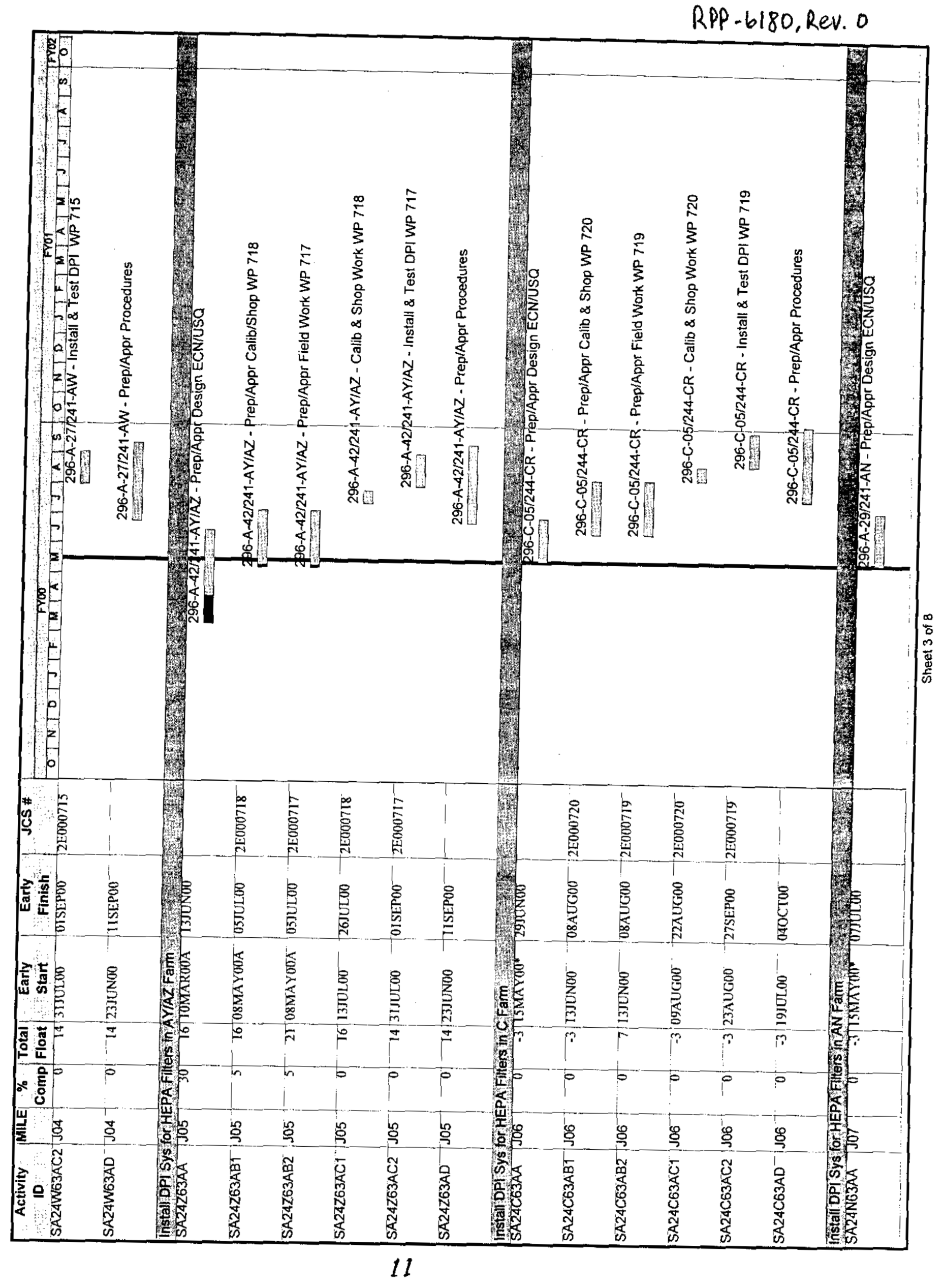


RPP -6180, Rev. 0

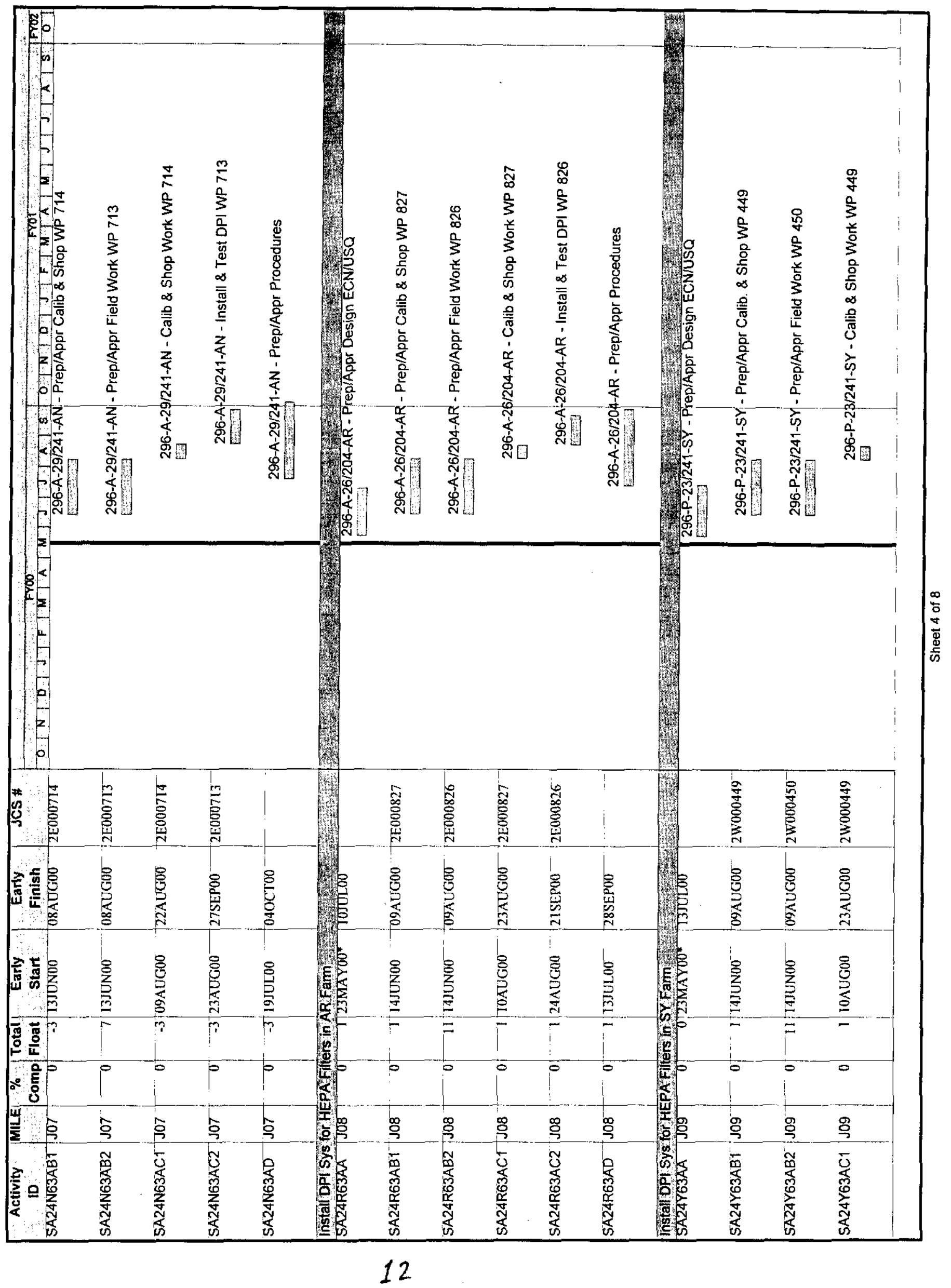


RPP-6180, Rev. 0

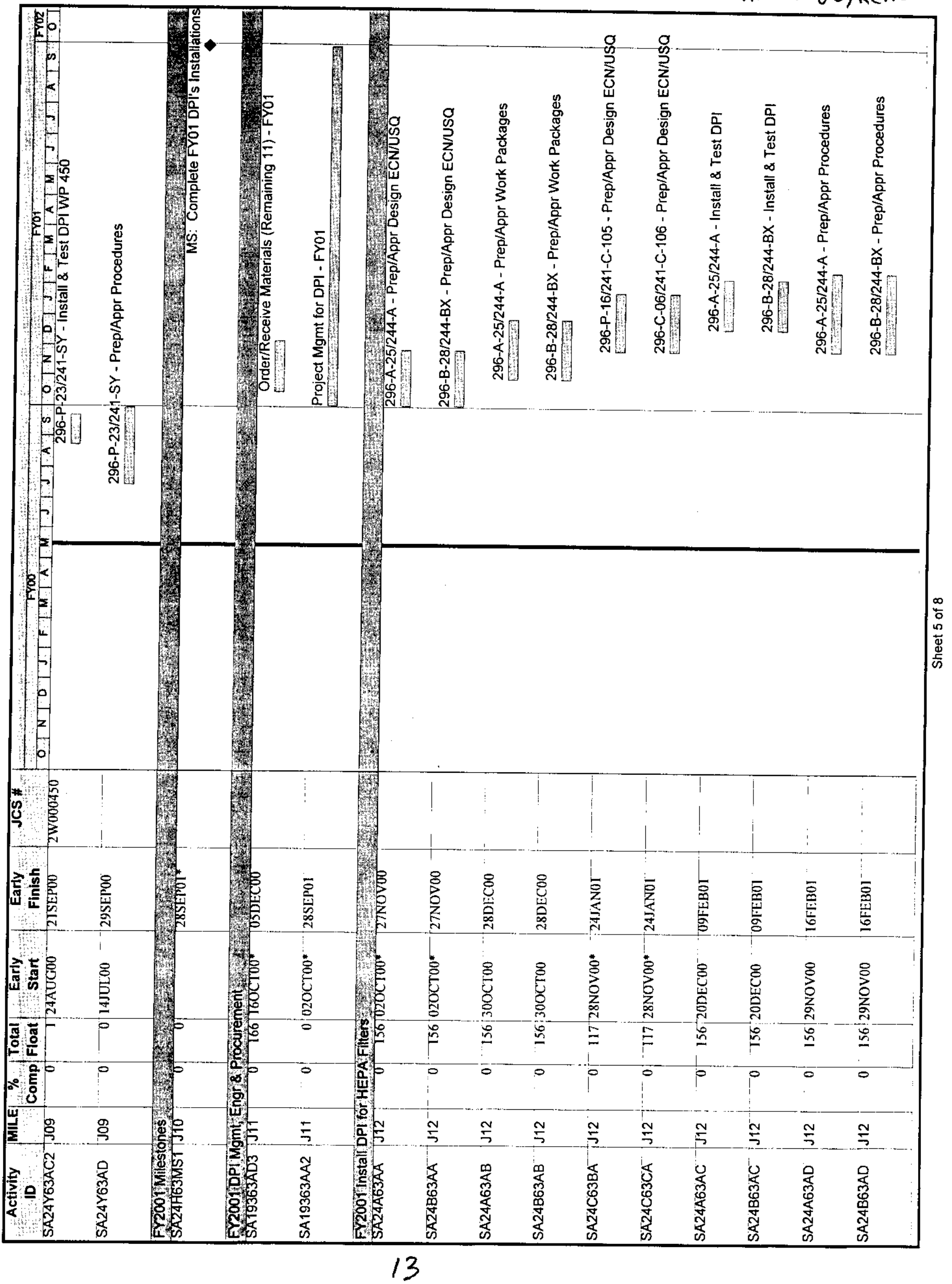




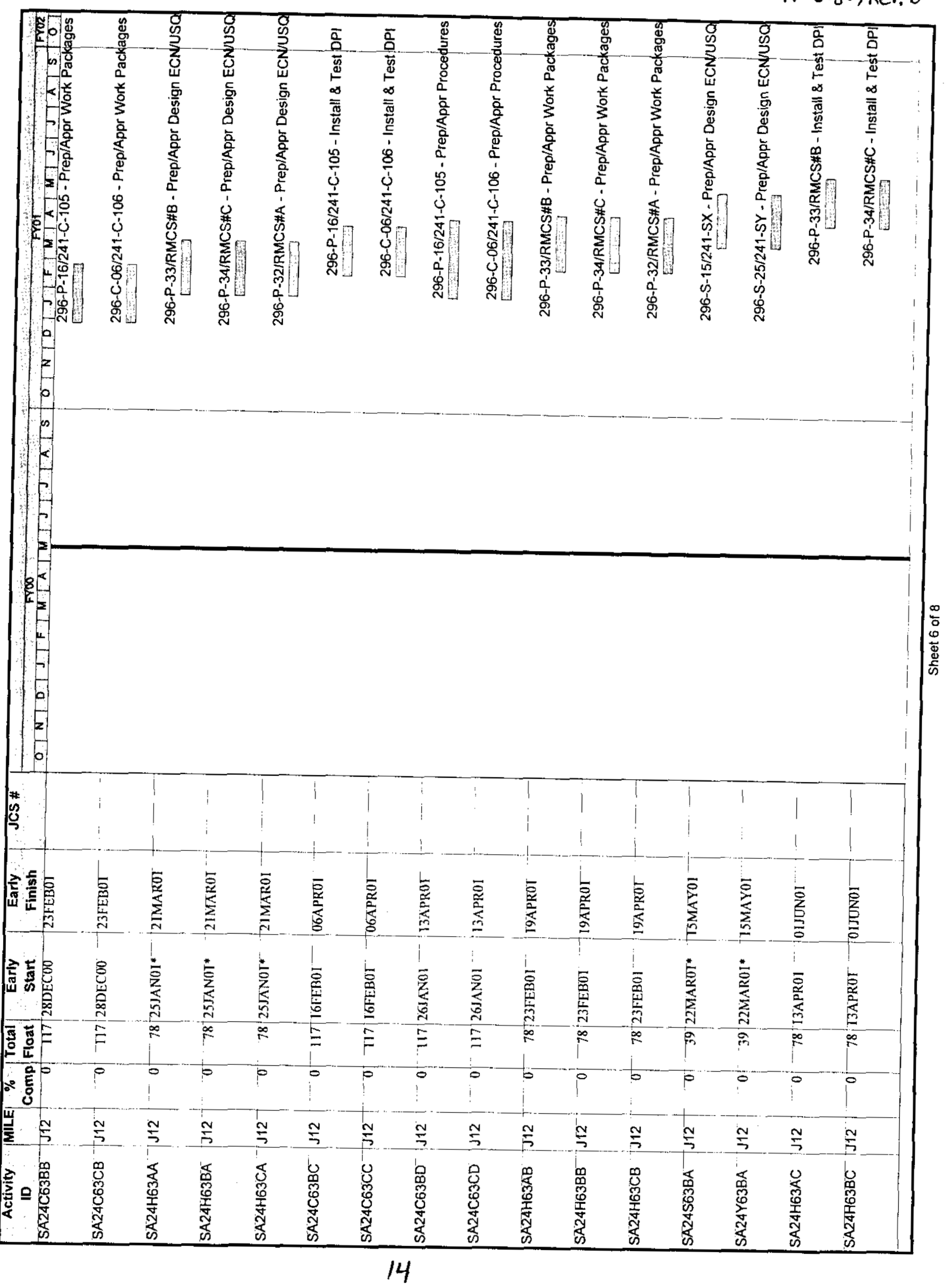




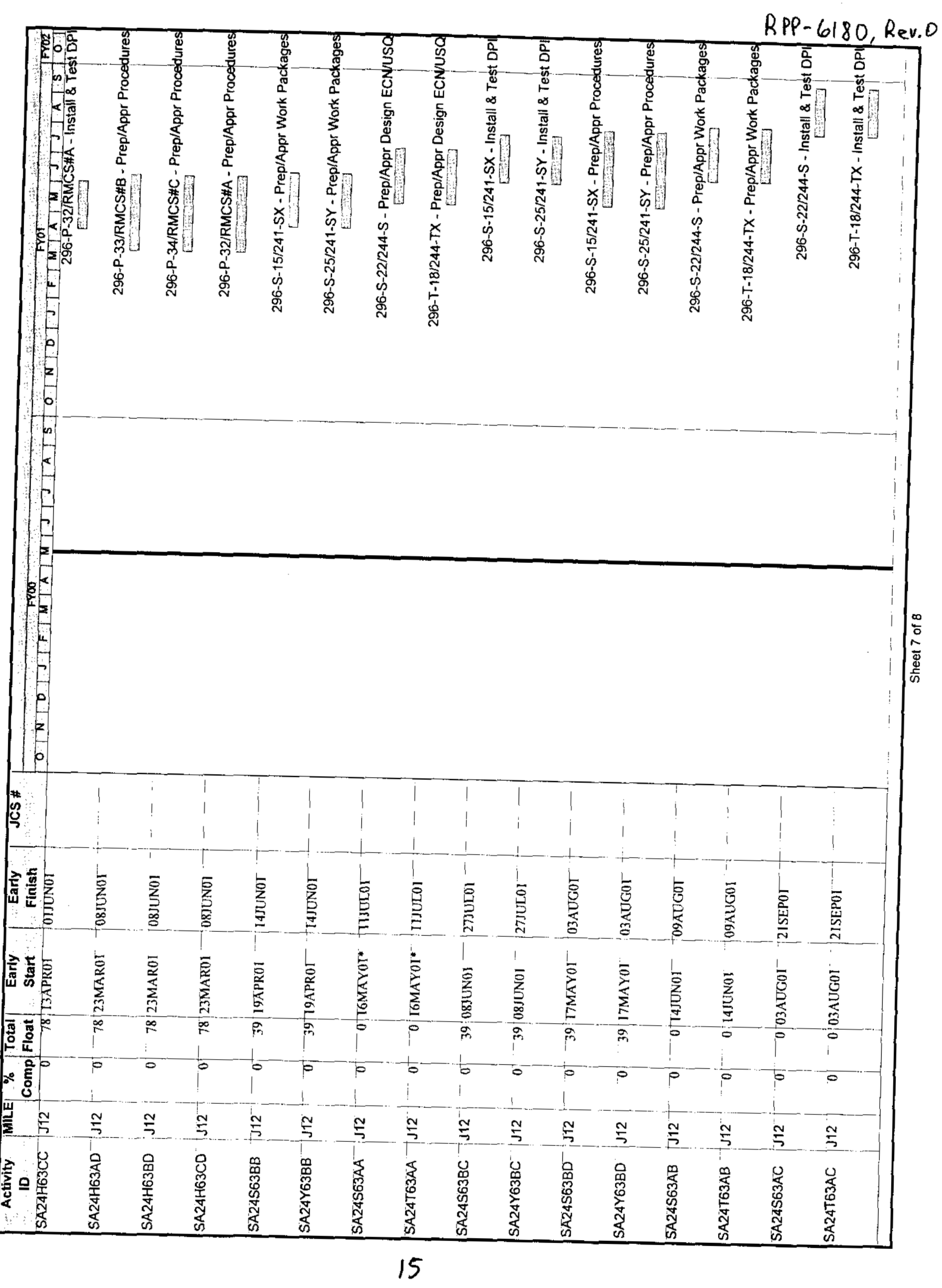




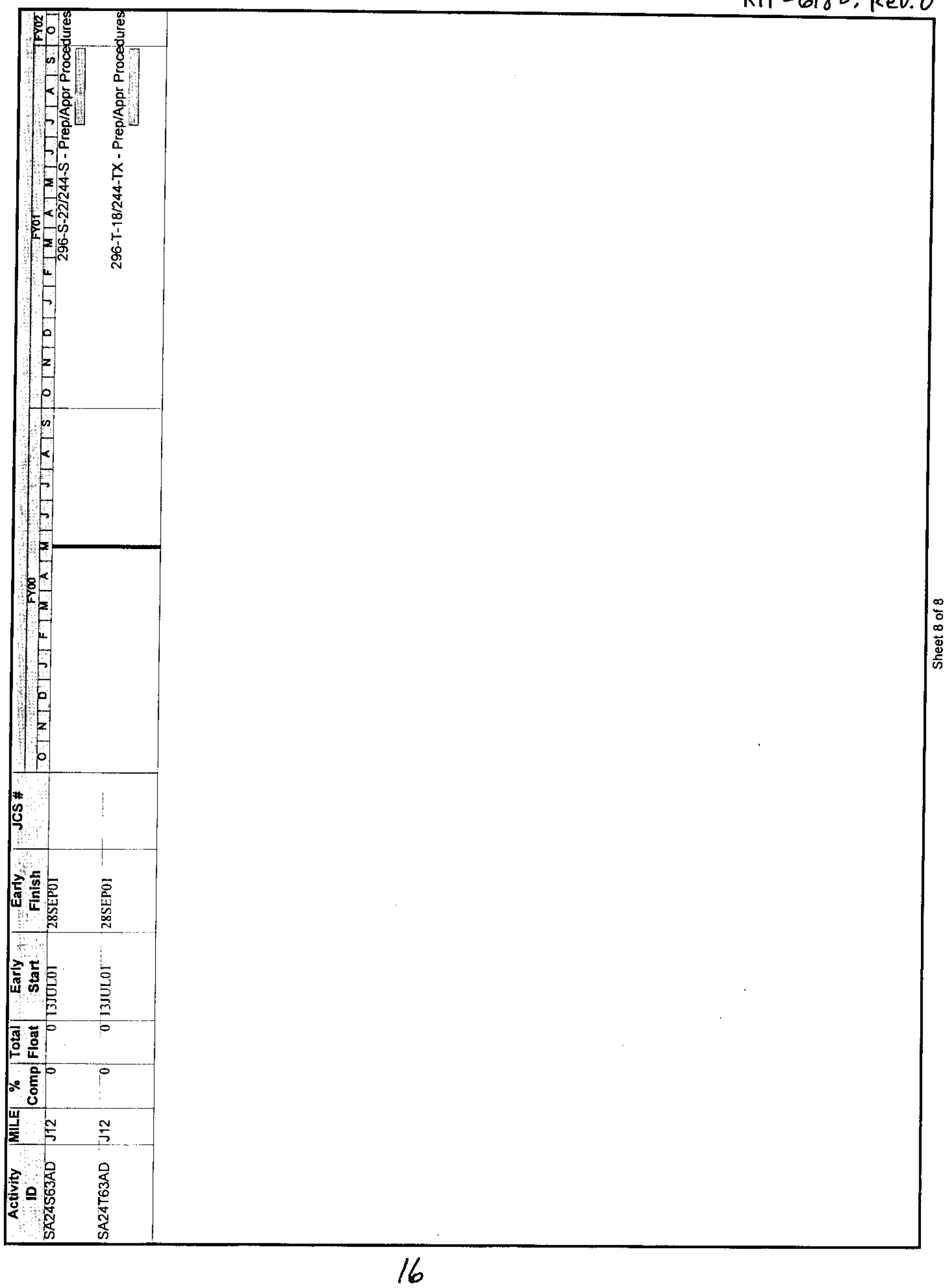

